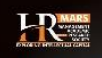 INTERNATIONAL JOURNAL OF ACADEMIC

\section{Fraudulent Financial Reporting Cases in Malaysia: A Descriptive Analysis}

\author{
Noora'in Omar, Mohd 'Atef Md Yusof
}

To Link this Article: http://dx.doi.org/10.6007/IJARAFMS/v11-i1/8528

DOI:10.6007/IJARAFMS /v11-i1/8528

Received: 18 January 2021, Revised: 20 February 2021, Accepted: 16 March 2021

Published Online: 27 March 2021

In-Text Citation: (Omar \& Yusof, 2021)

To Cite this Article: Omar, N., \& Yusof, M. 'Atef M. (2021). Fraudulent Financial Reporting Cases in Malaysia: A Descriptive Analysis. International Journal of Academic Research in Accounting Finance and Management Sciences, 11(1), 362-380.

\section{Copyright: (C) 2021 The Author(s)}

Published by Human Resource Management Academic Research Society (www.hrmars.com)

This article is published under the Creative Commons Attribution (CC BY 4.0) license. Anyone may reproduce, distribute, translate and create derivative works of this article (for both commercial and non-commercial purposes), subject to full attribution to the original publication and authors. The full terms of this license may be seen

at: $\underline{\text { http://creativecommons.org/licences/by/4.0/legalcode }}$

Vol. 11, No. 1, 2021, Pg. 362 - 380

http://hrmars.com/index.php/pages/detail/IJARAFMS

JOURNAL HOMEPAGE

Full Terms \& Conditions of access and use can be found at http://hrmars.com/index.php/pages/detail/publication-ethics 


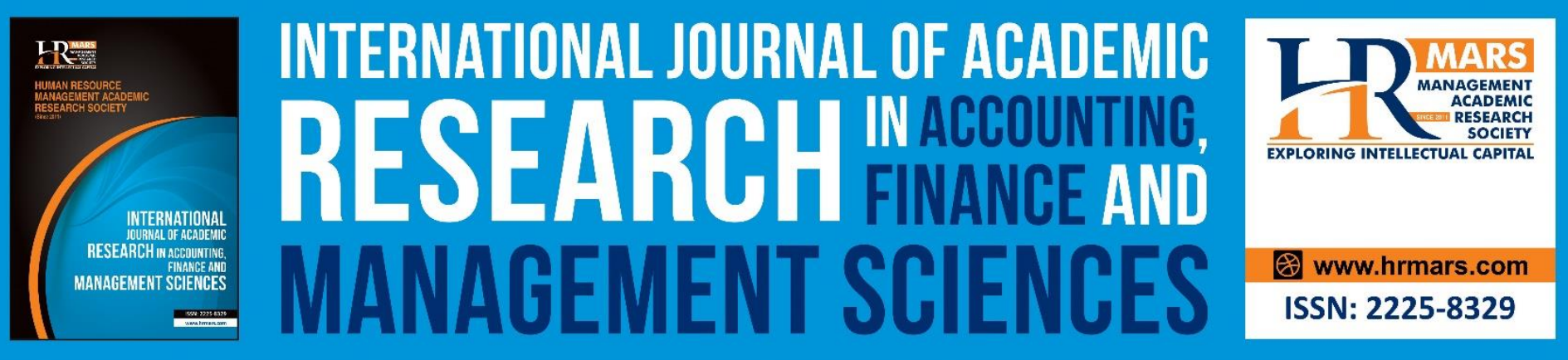

\title{
Fraudulent Financial Reporting Cases in Malaysia: A Descriptive Analysis
}

\author{
Noora'in Omar \\ Universiti Teknologi Mara Cawangan Kedah \\ Email: noorain@uitm.edu.my \\ Mohd 'Atef Md Yusof \\ Universiti Utara Malaysia \\ Email: atef@uum.edu.my
}

\begin{abstract}
The objective of this study is to explore the background of the companies involved in fraudulent financial reporting and the impacts to the offenders as well as the companies after the fraud was revealed by the regulator. In Malaysia, the main regulator empowered to investigate fraudulent financial reporting case is Securities Commission of Malaysia. The offenders involved in furnishing false information to the Securities Commission or Bursa Malaysia were charged under Capital Market and Services Act 2007. Prior to 2007, the offenders were charged under Securities Industry Act 1983. In this study, the fact of the case of 22 fraudulent companies listed in the criminal prosecution under enforcement action of Securities Commission of Malaysia's website were extracted and analyzed. The results reveal that most fraudulent financial reporting cases occurred a few years before the introduction Malaysian Code of Corporate Governance (MCCG) 2000 and a few years before the MCCG was revised in 2007. Industrial product sector was the sector most frequently involved in fraudulent financial reporting. The financial reports were manipulated in three aspects namely audited accounts, quarterly reports and corporate proposals. In most cases, the offenders involved in such fraud scheme were the top management mostly directors.
\end{abstract}

Keywords: Fraudulent Financial Reporting, Securities Commission, Fraud, Case, Malaysia

\section{Introduction}

Fraudulent financial reporting has been an issue of great concern worldwide following the collapsed of once venerable companies such as Enron and WorldCom. Fraudulent financial reporting is a category occupational fraud a long side with asset misappropriation and corruption. It is a fraud schemes, in which the perpetrator intentionally causes a material misstatement or omission in the organization's financial statements. According to the 2020 Global study on occupational fraud and abuse which analyzed 2,504 cases between January 2018 and September 2019, fraudulent financial 
INTERNATIONAL JOURNAL OF ACADEMIC RESEARCH IN ACCOUNTING, FINANCE AND MANAGEMENT SCIENCES

Vol. 11, No. 1, 2021, E-ISSN: 2225-8329 ๑ 2021 HRMARS

reporting is the least used scheme (10\% of cases) yet the costliest category of occupational fraud. It results in median loss of USD 954,000 per case (ACFE, 2020). In other words, it is reported as the first rank of enormous losses. Asset misappropriation which involves an employee stealing or misusing the employing organization's resources, occurs in the vast majority of fraud schemes (86\% of cases) however, these schemes produce the lowest median loss at USD 100,000 per case. The third category, corruption which includes offenses such as bribery, conflicts of interest, and extortion falls in the middle in terms of both frequency and financial damage. This scheme occurs in $43 \%$ of cases and cause a median loss of USD 200,000. Since these three types of fraud are frequently undetected and often never reported, so it is difficult to determine the full scope of global losses.

In Malaysia, fraudulent financial reporting cases have started to surface even before the collapse of Enron. Based on the securities commission enforcement record, the first case of submitting false information was committed by the director of Ganad Corporation Bhd in 1995. Towards the end of 1990's, a few more similar cases arose in companies such as Kiara Emas Asia Industries Bhd and Chase Perdana Bhd. The highest frequency of such fraud occurred between 2004 and 2007 involving companies such as Transmile Group Bhd, Welli Multi Corporation Bhd and MEMS Technology Bhd (Wan Abdullah et al., 2012). Prior to 2007, the offences related to fraudulent financial reporting were charged under Securities Industry Act 1983. Later, the cases were charged under Capital Market and Services Act 2007 (CMSA) when this new Act came into force on 28 September 2007 (Sulaiman, 2008).

The widespread occurrence of fraudulent financial reporting has led researchers to conduct study in various aspect of fraudulent financial reporting. The review of previous literatures on fraudulent financial reporting reveals that many empirical studies have been carried out by researchers in the area of fraudulent financial reporting or in a similar area. Much research was carried out within the purview of audit (Bonner et al., 1998; Carcello \& Nagy, 2004; Kinney et al., 2004; Knapp \& Knapp, 2001; Owusu-Ansah et al., 2002). Others were related to detection of fraud (Barsky et al., 2003; Kaminski et al., 2004; Persons, 1995; Spathis, 2002); the characteristics that predispose fraudulent financial reporting (Beasley, 1996; Holtfreter, 2005; Lavery et al., 2000; Saksena, 2001; Summers \& Sweeney, 1998; Turpen \& Messina, 1997); behavioural intention (Carpenter \& Reimers, 2005; Yusoff et al., 2020; Weidman et al., 2004); the effect of establishment of audit committee on fraudulent financial reporting (Badolato et al., 2013; Beasley, 1996; Ghafran, 2013; Huang \& Thiruvadi, 2010); managerial ownership (Baek et al., 2009; Chen et al., 2006); ownership concentration (Al-Rassas \& Kamardin, 2015); motives for fraudulent financial reporting (Kanjanapathy \& Hashim, 2019; Lau \& Ooi, 2016) and fraud prevention (Azis et al., 2020).

However, to this date, no study in Malaysia has been specifically conducted to explore the background of the companies involved in fraudulent financial reporting and the impacts to the offenders as well as the companies after the fraud was revealed by the regulator. If this study is not carried out, the overall understanding about the background of the companies involved in fraudulent financial reporting and the impacts to the offenders as well as the companies after the fraud was revealed will be unclear. Therefore, this study attempts to explore the background of the companies involved in fraudulent financial reporting and the impacts to the offenders as well as the companies after the fraud was revealed by the regulator. 
INTERNATIONAL JOURNAL OF ACADEMIC RESEARCH IN ACCOUNTING, FINANCE AND

MANAGEMENT SCIENCES

Vol. 11, No. 1, 2021, E-ISSN: $2225-8329$ @ 2021 HRMARS

\section{Literature Review}

\section{Fraudulent Financial Reporting}

Fraudulent financial reporting is defined as the intentional, deliberate, misstatement or omission of material facts, or accounting data to mislead and, when considered with all the information made available, would cause the reader to alter his or her judgment in making a decision, usually with regards to investments (ACFE, 2020). In other words, the fraudulent financial reporting is generally defined as the intended deceives or misrepresents in one way to others (Zin et al., 2020). There are five basics of financial statement fraud, which are fictitious sales, improper expenses recognition, incorrect asset valuation, hidden liabilities and unsuitable disclosures (Mat Zin et al., 2020). Fraudulent financial reporting may occur anywhere and has become increasingly prominent in the eyes of the public and the world's regulators as it may be committed by individuals across all professions. Reinstein, Moehrle and Reynolds-Moehrle (2006) documented that financial statement fraud begins with financial and morale problems in the company, in which the company's control environment is lacking which encourages inefficiency within its auditing procedures. These findings were supported by Carcello and Palmrose (1994); Dechow, Hutton and Sloan (1996) and Lys and Watts (1994) who found that financial distress and poor financial performances are the most important reason for financial statement fraud occurrences. While occurring less often than other types of fraud, fraudulent financial reporting usually does the most harm to organizations (Dalnial et al., 2014). As a consequence, fraudulent financial reporting has received much attention from the public, the financial community and regulatory bodies.

\section{Enforcement Action in Malaysia}

The main statute regulating the securities market in Malaysia is Capital Market and Services Act 2007 (CMSA). Under the CMSA, the Securities Commission is authorized to initiate criminal proceedings as well as civil actions for contravention of the securities law, in addition to administrative sanctions that may be imposed without having recourse to the courts. The CMSA is a consolidating Act which now encompasses the former Securities Industry Act 1983, the Futures Industry Act 1993 and Part IV of the Securities Commission Act 1993 which deals with fund raising activities. The CMSA is supported by the Capital Markets and Services Regulations 2007, the Licensing Handbook and the Guidelines on Regulation of Markets. The CMSA which was passed by Parliament in May 2007, came into force on 28 September 2007 (Sulaiman, 2008). Hence, any public listed companies involves in fraudulent financial reporting will now be charged under CMSA.

\section{Methodology}

The sample data of this study consist of 22 public listed companies that were involved in fraudulent financial reporting. They were manually identified from the criminal prosecution list under enforcement action of Securities Commission of Malaysia's website. There are various types of offences being listed under criminal prosecution such as furnishing false information, money laundering, insider trading, criminal breach of trust, short selling, market manipulation, illegal fund management activities and defrauding a stockbroking company. The offence relates to fraudulent financial reporting is furnishing false information either to Securities Commission of Malaysia or Bursa Malaysia Berhad (previously known as Kuala Lumpur Stock Exchange (KLSE)). The offence was previously charged under section $122 \mathrm{~B}$ and 122C of Securities Industry Act 1983. Now, the offence is charged under section 369 and 370 of Capital Market and Services Act 2007 (Sulaiman, 2008). The 
INTERNATIONAL JOURNAL OF ACADEMIC RESEARCH IN ACCOUNTING, FINANCE AND MANAGEMENT SCIENCES

Vol. 11, No. 1, 2021, E-ISSN: 2225-8329 @ 2021 HRMARS

information about the offender, the fact of the case and the penalty imposed were extracted from the criminal prosecution record of Securities Commission of Malaysia. Additional information related to the type of market, the business sector, year of delisting, the availability of annual report and the auditor that audited the companies in the year of fraud is obtained from the Bursa Malaysia website.

\section{Findings and Discussions}

This section will discuss the findings of the study. The discussion will first describe the background of the fraudulent companies then followed by discussing the impacts to the offenders as well as the companies after the fraud was revealed.

Table 1.1: Summary of the type of market, the business sector, year of delisting, the availability of annual report and the auditor

\begin{tabular}{|c|c|c|c|c|c|c|}
\hline No & Name of Company & YOF & $\begin{array}{l}\text { Marke } \\
\text { t }\end{array}$ & Sector & De-listing & Audit Firm \\
\hline 1 & $\begin{array}{l}\text { Ganad Corporation } \\
\text { Bhd }\end{array}$ & 1995 & Main & IP & $\begin{array}{l}\text { No Annual } \\
\text { Report }\end{array}$ & No information \\
\hline 2 & $\begin{array}{l}\text { Westmont Industries } \\
\text { Bhd }\end{array}$ & 1996 & Main & IP & $\begin{array}{l}\text { No Annual } \\
\text { Report }\end{array}$ & No information \\
\hline 3 & $\begin{array}{l}\text { Kiara Emas Asia } \\
\text { Industries Bhd }\end{array}$ & $\begin{array}{l}1997- \\
2000\end{array}$ & Main & $\mathrm{CP}$ & $\begin{array}{l}\text { No Annual } \\
\text { Report }\end{array}$ & No information \\
\hline 4 & $\begin{array}{l}\text { Wembley Industries } \\
\text { Holdings Bhd }\end{array}$ & 1998 & Main & Properties & $15 / 09 / 2008$ & $\begin{array}{l}\text { Arthur Andersen\& } \\
\text { Co }\end{array}$ \\
\hline 5 & Chase Perdana Bhd & 1998 & Main & IP & $22 / 05 / 2008$ & $\begin{array}{l}\text { Shamsir Jasani } \\
\text { Grant Thorton }\end{array}$ \\
\hline 6 & $\begin{array}{l}\text { Idris Hydraulic (M) } \\
\text { Bhd }\end{array}$ & 1999 & Main & Financial & $\begin{array}{l}\text { No Annual } \\
\text { Report }\end{array}$ & No information \\
\hline 7 & Tat Sang Holdings Bhd & 2000 & Main & CP & $27 / 10 / 2003$ & Saw \& Co. \\
\hline 8 & $\begin{array}{l}\text { Pilecon Engineering } \\
\text { Bhd }\end{array}$ & 2001 & Main & $\begin{array}{l}\text { Constructio } \\
\mathrm{n}\end{array}$ & $14 / 01 / 2010$ & $\begin{array}{l}\text { HLB I.M. Chieng \& } \\
\text { Co }\end{array}$ \\
\hline 9 & $\begin{array}{l}\text { Plantation and } \\
\text { Development (M) Bhd }\end{array}$ & 2001 & Main & Properties & $22 / 09 / 2010$ & $\begin{array}{l}\text { Arthur Andersen\& } \\
\text { Co }\end{array}$ \\
\hline 10 & $\begin{array}{l}\text { Polymate } \text { Holdings } \\
\text { Bhd (PHB) }\end{array}$ & 2003 & Main & IP & 19/10/2006 & $\begin{array}{l}\text { Ahmad Abdullah \& } \\
\text { Goh }\end{array}$ \\
\hline 11 & $\begin{array}{l}\text { United } \\
\text { Corporation Bhd }\end{array}$ & 2004 & Main & IP & & $\begin{array}{l}\text { Roger Yue, Tan \& } \\
\text { Associates }\end{array}$ \\
\hline 12 & Transmile Group Bhd & $\begin{array}{l}2004- \\
06\end{array}$ & Main & $T \& S$ & $24 / 05 / 2011$ & Deloitte \& Touche \\
\hline 13 & $\begin{array}{l}\text { INIX Technologies } \\
\text { Holdings Bhd }\end{array}$ & 2005 & Ace & Technology & & $\begin{array}{l}\text { Azman, } \\
\text { Salleh \& Co }\end{array}$ \\
\hline 14 & $\begin{array}{l}\text { Welli Multi } \\
\text { Corporation Bhd }\end{array}$ & 2005 & Main & IP & $17 / 08 / 2009$ & $\begin{array}{l}\text { Deloittee Kassim } \\
\text { Chan }\end{array}$ \\
\hline 15 & $\begin{array}{l}\text { Kosmo Technology } \\
\text { Industrial Bhd }\end{array}$ & 2006 & Main & IP & 09/06/2009 & $\begin{array}{l}\text { Shamsir Jasani } \\
\text { Grant Thorton }\end{array}$ \\
\hline
\end{tabular}


INTERNATIONAL JOURNAL OF ACADEMIC RESEARCH IN ACCOUNTING, FINANCE AND MANAGEMENT SCIENCES

Vol. 11, No. 1, 2021, E-ISSN: 2225-8329 @ 2021 HRMARS

\begin{tabular}{|c|c|c|c|c|c|c|c|}
\hline 16 & $\begin{array}{l}\text { Megan } \\
\text { Holding }\end{array}$ & s Bhd & 2006 & Main & IP & $23 / 04 / 2008$ & KPMG \\
\hline 17 & Satang & Holdings Bhd & 2007 & Main & IP & & Leou \& Associates \\
\hline 18 & LFE Cor & poration Bhd & 2007 & Main & T\&S & & KPMG \\
\hline 19 & $\begin{array}{l}\text { MEMS } \\
\text { Bhd }\end{array}$ & Technology & $\begin{array}{l}2007- \\
09\end{array}$ & Ace & Technology & $12 / 11 / 2010$ & KPMG \\
\hline 20 & $\begin{array}{l}\text { Axis } \\
\text { Bhd }\end{array}$ & Incorporation & $\begin{array}{l}2007- \\
08\end{array}$ & Main & IP & 03/06/2011 & Crowe Horwath \\
\hline 21 & $\begin{array}{l}\text { Linear } \\
\text { Bhd }\end{array}$ & Corporation & 2009 & Main & IP & & $\begin{array}{l}\text { Wong Liu } \quad \& \\
\text { Partners }\end{array}$ \\
\hline 22 & Silverbi & rd Bhd & $\begin{array}{l}2010- \\
11\end{array}$ & Main & $\mathrm{CP}$ & $24 / 10 / 2014$ & Crowe Horwath \\
\hline
\end{tabular}

Table 1.1 above shows that $90.9 \%$ (20 companies) of the companies were under main market. Five companies were identified to have committed fraud repeatedly. Kiara Emas Asia Industries Bhd repeated fraud for four consecutive years. Transmile Group Bhd and MEM Technology Bhd repeated fraud for three consecutive years. Whilst, Axis Incorporation Bhd and Silverbird Bhd repeated fraud for two consecutive years. The repeated fraud led to increase in observation to 31 . The frequency of fraud eventually turned out to be as in Table 1.2 below

Table 1.2: Frequency of fraud

\begin{tabular}{ll}
\hline Year & Frequency \\
\hline 1995 & 1 \\
\hline 1996 & 1 \\
\hline 1997 & 1 \\
\hline 1998 & 3 \\
\hline 1999 & 2 \\
\hline 2000 & 2 \\
\hline 2001 & 2 \\
\hline 2003 & 1 \\
\hline 2004 & 2 \\
\hline 2005 & 3 \\
\hline 2006 & 3 \\
\hline 2007 & 4 \\
\hline 2008 & 2 \\
\hline 2009 & 2 \\
\hline 2010 & 1 \\
\hline 2011 & 1 \\
\hline Total & 31 \\
\hline
\end{tabular}

Table 1.2 above indicates that most fraudulent financial reporting cases occurred between 1998 and 2001 and later between 2004 and 2007. The frequency of occurrence between 1998 and 2001 occurred before Malaysian Code of Corporate Governance 2000 (MCCG) became effective. The 
INTERNATIONAL JOURNAL OF ACADEMIC RESEARCH IN ACCOUNTING, FINANCE AND MANAGEMENT SCIENCES

Vol. 11, No. 1, 2021, E-ISSN: 2225-8329 @ 2021 HRMARS

occurrence of fraud cases during this period that led to the introduction MCCG 2000 which aimed to promote sound corporate governance standards in Malaysia (Md Nasir \& Hashim, 2020). During that period, weak corporate governance structures were believed to be the reason behind the financial statement fraud (Yang et al., 2017). Later, the frequency of fraudulent financial reporting cases were on the rise again between 2004 and 2007 could be attributed to the fact that at that time MCCG was still at its infancy stage and required improvements. As a consequence, the MCCG was revised in 2007 to strengthen the effectiveness of the corporate governance as a control mechanism to prevent fraud. As for frequency of fraud among business sector, it be summarised as Table 1.3 below.

Table 1.3: Frequency of business sector

\begin{tabular}{lll}
\hline Sector & Frequency & Percent \\
\hline Construction & 1 & $5 \%$ \\
\hline Consumer product & 3 & $14 \%$ \\
\hline Financial & 1 & $5 \%$ \\
\hline Industrial product & 11 & $50 \%$ \\
\hline Properties & 2 & $9 \%$ \\
\hline Technology & 2 & $9 \%$ \\
\hline Trading and services & 2 & $9 \%$ \\
\hline Total & $\mathbf{2 2}$ & $\mathbf{1 0 0 \%}$ \\
\hline
\end{tabular}

The Table 1.3, above reveals that $50 \%$ (11 companies) of the fraudulent companies came from industrial product sector. The justification could be due to weakness in the internal control system and the complexity of industrial product business. Such weaknesses provided opportunity for the offenders to commit fraud.

Next, by referring back to Table 1.1, the annual report of four fraudulent companies have been removed from the Bursa Malaysia website namely Ganad Corporation Bhd, Westmont Industries Bhd, Kiara Emas Asia Industries Bhd and Idris Hydraulic (M) Bhd. The possible reason could be that they have filed for bankruptcy or changed status to private companies. As a consequence, information about the auditor for these four companies cannot be obtained. Table 1.1 also reveals that thirteen companies were delisted from Bursa Malaysia. They were either ceased operation or changed status to private companies.

In relation to auditor, two fraudulent companies (Wembley industries Bhd and Plantation and Development (M) Bhd) were audited by Arthur Anderson which was in the Big 5 group before 2002 . Nevertheless, Arthur Anderson was doomed to cease operation in 2002 following the collapse of Enron in the USA. Since then, the professional accountancy service network shrunk to Big 4. The current Big 4 firms comprise accounting network Deloitte, Ernst \& Young KPMG and PricewaterhouseCoopers. After 2002, four companies were audited by Big 4. Transmile Group Bhd was audited by Deloittee and Touche, whilst Megan Media Holdings Bhd, LFE Corporation Bhd and MEMS Technology were audited by KPMG. This finding indicates that engaging Big 4 to audit the company does not give any guarantee that the occurrence of fraudulent financial reporting could be prevented. Lindsey et al. (2002) stated among the factors that cause audit failure are weak internal 
INTERNATIONAL JOURNAL OF ACADEMIC RESEARCH IN ACCOUNTING, FINANCE AND MANAGEMENT SCIENCES

Vol. 11, No. 1, 2021, E-ISSN: 2225-8329 @ 2021 HRMARS

control, weak or non-existence of audit committee, auditor offered non-audit services which affect independence, failure on part of auditor to enquire about fraud and auditor fails to uphold appropriate professional standards in completing audit. Park (2017) claimed that powerful clients could also result in audit failure.

Next, this study discovered that five companies changed name a few years after they were involved in fraud. First, Ganad Corporation Bhd which changed name to Axis Incorporation Bhd in 2005. Second, Plantation and Development (M) Bhd which changed name to Fountain View Development Bhd in 2003. Third, Welli Multi Corporation Bhd which changed name to Energreen Corporation Bhd in 2008. Next, Satang Holdings Bhd which changed name to Destini Bhd in 2011 and the fifth one Silverbird Bhd which is now known as High-5 Conglomerate Bhd since 2013.

Table 1.4: Summary of fact of case and penalty

\begin{tabular}{|c|c|c|c|c|c|}
\hline No & $\begin{array}{l}\text { Name of } \\
\text { Company }\end{array}$ & YOF & $\begin{array}{l}\text { Offende } \\
r\end{array}$ & Fact of case & Penalty/Sentence \\
\hline 1. & $\begin{array}{l}\text { Ganad } \\
\text { Corporatio } \\
\text { n Bhd }\end{array}$ & 1995 & Director & $\begin{array}{l}\text { Gan, a director of Ganad } \\
\text { Corporation Bhd (Ganad), was } \\
\text { charged for submitting false } \\
\text { information to the SC, which was } \\
\text { provided in Ganad's audited } \\
\text { accounts for two financial year ends, } \\
\text { in connection with Ganad's listing } \\
\text { proposal. The turnover, trade } \\
\text { debtors and profit before tax figures } \\
\text { reflected in the audited accounts } \\
\text { were inflated. }\end{array}$ & $\begin{array}{l}\text { Gan was fined } \\
\text { RM600,000 (in } \\
\text { default } 6 \text { months } \\
\text { imprisonment). The } \\
\text { fine was paid. }\end{array}$ \\
\hline 2. & $\begin{array}{l}\text { Westmont } \\
\text { Industries } \\
\text { Bhd }\end{array}$ & 1996 & Director & $\begin{array}{l}\text { Chong, Vincent and Chok had } \\
\text { caused the submission of misleading } \\
\text { information that is contained in the } \\
\text { unaudited results of Westmont } \\
\text { Industries Berhad Group for year } \\
\text { ended } 31 \text { December } 1996 \text { to KLSE. }\end{array}$ & $\begin{array}{l}\text { Chong was fined } \\
\text { RM400,000 (in } \\
\text { default } 12 \text { months } \\
\text { imprisonment). }\end{array}$ \\
\hline 3. & $\begin{array}{l}\text { Kiara Emas } \\
\text { Asia } \\
\text { Industries } \\
\text { Bhd }\end{array}$ & $\begin{array}{l}1997- \\
2000\end{array}$ & $\begin{array}{l}\text { Account } \\
\text { ant } \\
\text { Auditor }\end{array}$ & $\begin{array}{l}\text { Tan, a former accountant of Kiara } \\
\text { Emas Asia Industries Bhd (KEAIB) } \\
\text { and Ravandaran, a former audit } \\
\text { partner of Messrs. Arthur Andersen } \\
\text { \& Co. who was in-charge of KEAIB's } \\
\text { audit were both charged on } 13 \\
\text { August } 2004 \text { for furnishing false } \\
\text { information to the SC. The } \\
\text { information was said to be } \\
\text { contained in the "Follow Up } \\
\text { Questionnaires" of KEAIB for the }\end{array}$ & $\begin{array}{l}\text { On } 13 \text { December } \\
2012 \text {, both Tan and } \\
\text { Ravandaran were } \\
\text { acquitted and } \\
\text { discharged by the } \\
\text { Sessions Court at } \\
\text { the end of the } \\
\text { prosecution's case. }\end{array}$ \\
\hline
\end{tabular}




\begin{tabular}{|c|c|c|c|c|c|}
\hline & & & & $\begin{array}{l}\text { financial years ended } 31 \text { March } \\
\text { 1997, } 1998,1999 \text { and } 2000 \text { on the } \\
\text { status of the utilisation of proceeds } \\
\text { of a rights issue by KEAIB when in } \\
\text { fact RM16,937,739.20 of the right } \\
\text { issue proceeds had been utilized in } \\
\text { breach of the conditions of the } \\
\text { Securities Commissions' letter of } \\
\text { approval dated } 14 \text { November } 1996 \text {. }\end{array}$ & \\
\hline 4. & $\begin{array}{l}\text { Wembley } \\
\text { Industries } \\
\text { Holdings } \\
\text { Bhd }\end{array}$ & 1998 & Director & $\begin{array}{l}\text { Peter Ling, a director of Wembley } \\
\text { Industries Holdings Bhd (WIHB) was } \\
\text { charged for knowingly and willfully } \\
\text { permitting the furnishing of a false } \\
\text { statement to the KLSE in relation to } \\
\text { WIHB's affairs. The false statement } \\
\text { was in WIHB's announcement to } \\
\text { KLSE dated } 25 \text { February } 1998 \text { which } \\
\text { stated that none of the directors or } \\
\text { substantial shareholders of WIHB } \\
\text { have any interest, direct and/or } \\
\text { indirect, in the disposal of its } \\
\text { subsidiaries when in fact he had an } \\
\text { indirect interest in the disposal. }\end{array}$ & $\begin{array}{l}\text { Peter Ling was } \\
\text { acquitted } \\
\text { discharged on } 26 \\
\text { December 2008. }\end{array}$ \\
\hline 5. & $\begin{array}{l}\text { Chase } \\
\text { Perdana } \\
\text { Bhd }\end{array}$ & 1998 & $\begin{array}{l}\text { Executiv } \\
\text { e } \\
\text { chairma } \\
\mathrm{n}\end{array}$ & $\begin{array}{l}\text { Tan Sri Datuk Dr. Mohan, executive } \\
\text { chairman of Chase Perdana Berhad } \\
\text { (CPB), caused to be submitted false } \\
\text { information in CPB's corporate } \\
\text { proposal to the SC. The false } \\
\text { information was that he did not hold } \\
\text { any shares in CPB when in fact he } \\
\text { did. }\end{array}$ & $\begin{array}{l}\text { The executive } \\
\text { chairman was } \\
\text { compounded } \\
\text { RM1,000,000 for } \\
\text { the offence on } 30 \\
\text { January 2003. }\end{array}$ \\
\hline 6. & $\begin{array}{l}\text { Idris } \\
\text { Hydraulic } \\
\text { (M) Bhd }\end{array}$ & 1999 & Director & $\begin{array}{l}\text { Ishak, a director of Idris Hydraulic } \\
\text { (M) Berhad (IHMB), was charged on } \\
24 \text { July } 1999 \text { for falsely disclosing in } \\
\text { IHMB's proposal to the SC that he } \\
\text { did not hold any shares in KFC } \\
\text { Holdings (M) Bhd (KFC). } \\
\text { The information submitted was in } \\
\text { connection with a proposal for the } \\
\text { acquisition of an asset of KFC by } \\
\text { IHMB. }\end{array}$ & $\begin{array}{l}\text { He was fined } \\
\text { RM400,000 (in } \\
\text { default } 6 \text { months } \\
\text { imprisonment). }\end{array}$ \\
\hline
\end{tabular}




\begin{tabular}{|c|c|c|c|c|c|}
\hline 7. & $\begin{array}{l}\text { Tat Sang } \\
\text { Holdings } \\
\text { Bhd }\end{array}$ & 2000 & Director & $\begin{array}{l}\text { Lim, a director of Tat Sang Holdings } \\
\text { Bhd (Tat Sang), knowingly } \\
\text { authorised the furnishing of false } \\
\text { statements to the KLSE in respect of } \\
\text { Tat Sang's annual accounts for the } \\
\text { year ended } 31 \text { July 2000. The false } \\
\text { statements relate to: } \\
\text { Fixed assets balance that was } \\
\text { inflated through the inclusion of } \\
\text { fictitious invoices; } \\
\text { Other debtors balance that was } \\
\text { inflated through the inclusion of } \\
\text { payments pursuant to fictitious } \\
\text { agreements; and } \\
\text { Revenue figure that was inflated } \\
\text { through the inclusion of fictitious } \\
\text { sales. }\end{array}$ & $\begin{array}{l}\text { Lim was sentenced } \\
\text { to } \\
5 \text { months and } \\
\text { imposed a monetary } \\
\text { fine of RM } 200,000 \\
\text { (in default } 2 \text { months } \\
\text { imprisonment). }\end{array}$ \\
\hline 8. & $\begin{array}{l}\text { Pilecon } \\
\text { Engineerin } \\
\text { g Bhd }\end{array}$ & 2001 & $\begin{array}{l}\text { Executiv } \\
\mathrm{e} \\
\text { chairma } \\
\mathrm{n}\end{array}$ & $\begin{array}{l}\text { Tan, the Executive Chairman of } \\
\text { Pilecon Engineering Berhad } \\
\text { (Pilecon), failed to inform the SC } \\
\text { upon becoming aware that } \\
\text { information previously submitted to } \\
\text { SC may be misleading. } \\
\text { The information relates to the } \\
\text { directors' recommendation to } \\
\text { Pilecon's shareholder to vote in } \\
\text { favour of the extension of the } \\
\text { expiration date of Pilecon's warrants } \\
\text { that was contained in Pilecon's draft } \\
\text { circular to shareholders. }\end{array}$ & $\begin{array}{l}\text { The executive } \\
\text { chairman was } \\
\text { compounded } \\
\text { RM1,000,000. }\end{array}$ \\
\hline 9. & $\begin{array}{l}\text { Plantation } \\
\text { and } \\
\text { Developme } \\
\text { nt (M) Bhd }\end{array}$ & 2001 & $\begin{array}{l}\text { Director } \\
\mathrm{S}\end{array}$ & $\begin{array}{l}\text { Chua and Gwi, both directors of } \\
\text { Plantation \& Development Berhad } \\
\text { (P\&D), and Yong, the Chief Executive } \\
\text { Officer of P\&D, abetted P\&D in } \\
\text { utilising its public issue proceeds } \\
\text { amounting to RM26,493,335.57 for } \\
\text { purposes other than as approved by } \\
\text { SC. } \\
\text { Chua, also caused the submission of } \\
\text { a false statement to SC in relation to } \\
\text { the utilisation of the public issue } \\
\text { proceeds. }\end{array}$ & $\begin{array}{l}\text { The director was } \\
\text { fined } \mathrm{RM} 250,000 \text { (in } \\
\text { default } 6 \text { months } \\
\text { imprisonment). }\end{array}$ \\
\hline
\end{tabular}




\begin{tabular}{|c|c|c|c|c|c|}
\hline 10 & $\begin{array}{l}\text { Polymate } \\
\text { Holdings } \\
\text { Bhd }\end{array}$ & 2003 & $\begin{array}{l}\text { Managin } \\
\mathrm{g} \\
\text { director }\end{array}$ & $\begin{array}{l}\text { Ng, former Group Managing } \\
\text { Director of Polymate Holdings } \\
\text { Berhad (PHB) and Managing } \\
\text { Director of ABI Malaysia Sdn Bhd (its } \\
\text { wholly owned subsidiary), was } \\
\text { charged for knowingly authorising } \\
\text { the furnishing of false statements to } \\
\text { Bursa Malaysia, namely the inflated } \\
\text { revenue and trade receivables of } \\
\text { PHB for the year ended } 30 \\
\text { September 2003, as contained in } \\
\text { PHB's } 2003 \text { annual report. }\end{array}$ & $\begin{array}{l}\text { The director was } \\
\text { sentenced to a fine } \\
\text { of RM300,000 (in } \\
\text { default } 1 \text { year } \\
\text { imprisonment). }\end{array}$ \\
\hline 11 & $\begin{array}{l}\text { United U-Li } \\
\text { Corporatio } \\
\text { n Bhd }\end{array}$ & 2004 & $\begin{array}{l}\text { Managin } \\
\text { g } \\
\text { director } \\
\text { cum } \\
\text { chief } \\
\text { executiv } \\
\text { e officer }\end{array}$ & $\begin{array}{l}\text { Yue Chi Kin ("Yue") was charged } \\
\text { under section 122B (b)(bb) read } \\
\text { together with section } 122 \mathrm{C}(\mathrm{c}) \text { of the } \\
\text { Securities Industry Act } 1983 \text { for } \\
\text { abetting U-Li in making a misleading } \\
\text { statement to Bursa Malaysia in its } \\
\text { Annual Report and Financial } \\
\text { Statements for the financial year } \\
\text { ended } 31 \text { December } 2004 \text {. }\end{array}$ & $\begin{array}{l}\text { The managing } \\
\text { director cum chief } \\
\text { executive officer } \\
\text { was sentenced to } \\
\text { one year } \\
\text { imprisonment and a } \\
\text { fine of RM400,000. }\end{array}$ \\
\hline 12 & $\begin{array}{l}\text { Transmile } \\
\text { Group Bhd }\end{array}$ & $\begin{array}{l}2004- \\
06\end{array}$ & $\begin{array}{l}\text { Chief } \\
\text { financial } \\
\text { officer } \\
\text { cum } \\
\text { executiv } \\
\text { e } \\
\text { director }\end{array}$ & $\begin{array}{l}\text { Gan, former Chief Executive Officer } \\
\text { and Executive Director of Transmile } \\
\text { Group Berhad (Transmile) was } \\
\text { charged for abetting Transmile in } \\
\text { making a misleading statement } \\
\text { relating to Transmile's revenue in } \\
\text { the company's Quarterly Report on } \\
\text { Unaudited Consolidated Results for } \\
\text { the Financial Year ended } 31 \\
\text { December } 2006 \text { which was likely to } \\
\text { induce the purchase of Transmile's } \\
\text { shares by other persons, an offence } \\
\text { under section } 86 \text { (b) read together } \\
\text { with section } 122 C \text { (c) of the } \\
\text { Securities Industry Act } 1983 \text { (SIA). } \\
\text { Gan was also charged in alternative } \\
\text { with intent to deceive, furnished a } \\
\text { misleading statement to Bursa } \\
\text { Malaysia in the same financial } \\
\text { statement, an offence under section } \\
\text { 122B(a)(bb) read together with } \\
\text { section 122(1) of the SIA. }\end{array}$ & $\begin{array}{l}\text { The chief financial } \\
\text { officer cum } \\
\text { executive director } \\
\text { was sentenced to a } \\
\text { fine of RM2.5million } \\
\text { (in default, } 18 \\
\text { months' } \\
\text { imprisonment) and } \\
1 \text { day imprisonment. }\end{array}$ \\
\hline
\end{tabular}




\begin{tabular}{|c|c|c|c|c|c|}
\hline $\begin{array}{l}13 \\
.\end{array}$ & $\begin{array}{l}\text { INIX } \\
\text { Technologi } \\
\text { es Holdings } \\
\text { Bhd }\end{array}$ & 2005 & $\begin{array}{l}\text { Director } \\
\text { S } \\
\text { Senior } \\
\text { account } \\
\text { executiv } \\
\text { e }\end{array}$ & $\begin{array}{l}\text { Mok, Cheong \& Jimmy (directors of } \\
\text { Inix Technologies Holdings Bhd) } \\
\text { were charged with } 4 \text { charges under } \\
\text { s.122B(b)(bb) of the Securities } \\
\text { Industry Act } 1983 \text { (SIA) for } \\
\text { knowingly authorising the furnishing } \\
\text { of false statements to Bursa } \\
\text { Malaysia in relation to Inix's } 4 \\
\text { quarterly reports for FYE } 31 \text { July } \\
2006 \text {; i.e. } 31 \text { October } 2005,31 \text { Jan } \\
2006,30 \text { April } 2006 \text { and } 31 \text { July } \\
\text { 2006.In addition they were charged } \\
\text { under s.55(1)(a) of the Securities } \\
\text { Commission Act } 1993 \text { (SCA) for } \\
\text { causing the issuance of Inix's } \\
\text { Prospectus, which contained } \\
\text { information that is false. Normah } \\
\text { (Senior Account Executive of Inix) } \\
\text { was charged with abetting Jimmy in } \\
\text { committing all the offences set out } \\
\text { above. }\end{array}$ & $\begin{array}{l}\text { Jimmy was fined } \\
\text { RM400,000 and to } \\
\text { serve a total } \\
\text { sentence of } \\
\text { imprisonment of } 18 \\
\text { months. } \\
\text { Mok, Cheong and } \\
\text { Normah were fined } \\
\text { RM50,000 and are } \\
\text { to serve a total } \\
\text { sentence of } 12 \\
\text { months } \\
\text { imprisonment each. }\end{array}$ \\
\hline $\begin{array}{l}14 \\
.\end{array}$ & $\begin{array}{l}\text { Welli Multi } \\
\text { Corporatio } \\
\text { n Bhd }\end{array}$ & 2005 & $\begin{array}{l}\text { Chief } \\
\text { executiv } \\
\text { e officer } \\
\text { cum } \\
\text { executiv } \\
\text { e } \\
\text { director }\end{array}$ & $\begin{array}{l}\text { Ang Sun Beng was at the material } \\
\text { time the Managing Director of Welli } \\
\text { Multi Corporation Berhad (WMCB) } \\
\text { while co-director Ang Soon An was a } \\
\text { member of its Audit Committee. } \\
\text { They were each charged with four } \\
\text { counts under section } 122 \mathrm{~B}(\mathrm{a})(\mathrm{bb}) \\
\text { SIA } 1983 \text { read together with section } \\
122(1) \text { SIA } 1983 \text { for furnishing } \\
\text { misleading statements in WMCB's } \\
\text { annual report for FYE } 2005 \text { and the } \\
\text { first } 3 \text { quarterly reports of FYE } 2006 \\
\text { to the SC and Bursa Malaysia } \\
\text { Securities Berhad respectively. }\end{array}$ & $\begin{array}{l}\text { The Chief executive } \\
\text { officer cum } \\
\text { executive director } \\
\text { was compounded } \\
\text { RM100,000. }\end{array}$ \\
\hline 15 & $\begin{array}{l}\text { Kosmo } \\
\text { Technolog } \\
\text { y Industrial } \\
\text { Bhd }\end{array}$ & 2006 & $\begin{array}{l}\text { Managin } \\
\text { g } \\
\text { director } \\
\text { Executiv } \\
\text { e } \\
\text { director }\end{array}$ & $\begin{array}{l}\text { Norhamzah was at the material time } \\
\text { the Group Managing Director while } \\
\text { Mohd Azham was an executive } \\
\text { director of Kosmo Technology } \\
\text { Industrial Berhad ("Kosmo Tech"). } \\
\text { Both Norhamzah and Mohd Azham } \\
\text { were charged under section } \\
\text { 122B(a)(bb) read together with }\end{array}$ & $\begin{array}{l}\text { Norhamzah the MD } \\
\text { was sentenced to } \\
\text { imprisonment for a } \\
\text { total of } 2 \text { years and } \\
\text { is liable to a total } \\
\text { fine of RM1.45 } \\
\text { million. Mohd } \\
\text { Azham the ED was }\end{array}$ \\
\hline
\end{tabular}




\begin{tabular}{|c|c|c|c|c|c|}
\hline & & & $\begin{array}{l}\text { Account } \\
\text { Manage } \\
r\end{array}$ & $\begin{array}{l}\text { section } 122(1) \text { of the Securities } \\
\text { Industry Act } 1983 \text { and section } \\
369(a)(B) \text { read together with section } \\
367(1) \text { of the Capital Markets \& } \\
\text { Services Act } 2007 \text { for furnishing false } \\
\text { statements to Bursa Malaysia } \\
\text { Securities Berhad in relation to } \\
\text { Kosmo Tech's eight quarterly } \\
\text { reports on the unaudited } \\
\text { consolidated results for the financial } \\
\text { years } 2006 \text { and } 2007 . \\
\text { Lim Hai Loon, the Accounts Manager } \\
\text { of Kosmo Tech at the material time } \\
\text { was charged for abetting Kosmo } \\
\text { Tech in furnishing the false } \\
\text { statements to Bursa Malaysia } \\
\text { Berhad in relation to Kosmo Tech's } \\
\text { eight quarterly reports on the } \\
\text { unaudited consolidated results for } \\
\text { the financial years } 2006 \text { and } 2007 \text {. }\end{array}$ & $\begin{array}{l}\text { sentenced to } \\
\text { imprisonment for a } \\
\text { total of } 2 \text { years and } \\
\text { is liable to a total } \\
\text { fine of RM1.45 } \\
\text { million. Lim Hai Loon } \\
\text { the account } \\
\text { manager was } \\
\text { sentenced to } \\
\text { imprisonment for a } \\
\text { total of } 1 \text { year and is } \\
\text { liable to a total fine } \\
\text { of RM560,000. }\end{array}$ \\
\hline & $\begin{array}{l}\text { Megan } \\
\text { Media } \\
\text { Holdings } \\
\text { Bhd }\end{array}$ & 2006 & $\begin{array}{l}\text { Executiv } \\
\mathrm{e} \\
\text { chairma } \\
\mathrm{n} \quad \text { cum } \\
\text { director } \\
\text { Financial } \\
\text { controlle } \\
\mathrm{r}\end{array}$ & $\begin{array}{l}\text { The false information was in relation } \\
\text { to the revenue in MMHB's Quarterly } \\
\text { Report on Consolidated Results for } \\
\text { the Financial Period ended } 31 \\
\text { January } 2007 .\end{array}$ & $\begin{array}{l}\text { The executive } \\
\text { chairman } \quad \text { cum } \\
\text { director } \quad \text { was } \\
\text { sentenced } \\
\text { months } \\
\text { imprisonment and a } \\
\text { fine of RM300,000. }\end{array}$ \\
\hline 17 & $\begin{array}{l}\text { Satang } \\
\text { Holding } \\
\text { Bhd }\end{array}$ & 2007 & $\begin{array}{l}\text { Executiv } \\
\mathrm{e} \\
\text { chairma } \\
\mathrm{n} \text { and } \\
\text { managin } \\
\mathrm{g} \\
\text { director } \\
\text { Executiv } \\
\mathrm{e} \\
\text { Director } \\
\mathrm{s}\end{array}$ & $\begin{array}{l}\text { Jamaluddin (Executive Chairman } \\
\text { and Managing Director), Gan } \\
\text { (Executive Director) and Hakim } \\
\text { (Executive Director) were charged } \\
\text { with knowingly authorizing the } \\
\text { furnishing of false statements to } \\
\text { Bursa Malaysia in } 4 \text { of its quarterly } \\
\text { financial reports. }\end{array}$ & $\begin{array}{l}\text { Jamaluddin, Gan } \\
\text { and Hakim were } \\
\text { charged on } 4 \\
\text { December } 2008 . \\
\text { They were acquitted } \\
\text { by Sessions Court on } \\
17 \text { May } 2010 .\end{array}$ \\
\hline & $\begin{array}{l}\text { LFE } \\
\text { Corporatio } \\
\text { n Bhd }\end{array}$ & 2007 & Director & $\begin{array}{l}\text { Alan Rajendram a/l Jeya Rajendram, } \\
\text { a former director of LFE Corporation } \\
\text { Berhad (LFE), was charged on } 24 \\
\text { June } 2010 \text { with two charges under }\end{array}$ & $\begin{array}{l}\text { The director was } \\
\text { sentenced to a jail } \\
\text { term of } 12 \text { months } \\
\text { and a fine of }\end{array}$ \\
\hline
\end{tabular}


s.122B(b)(bb) of the SIA and two charges under $\mathrm{s.369(b)(B)}$ of the CMSA 2007 for knowingly permitting the furnishing of false statements by LFE to Bursa Malaysia Securities Berhad in relation to LFE's unaudited financial results for all four quarters for its financial year ended 31 December 2007. The false statements were in relation to fictitious purchases of RM119 million made by LFE International Ltd, a subsidiary of LFE.

\begin{tabular}{llll}
\hline 19 & MEMS & $2007-$ & Director \\
. Technolog & 09 & \\
& y Bhd
\end{tabular}

Ooi Boon Leong, the Director and substantial shareholder of Mems Technology Berhad, was charged for knowingly authorised the furnishing of a misleading statement to Bursa Malaysia Berhad. The misleading statement is in relation to Mems Technology Berhad group's revenue for year ended 31 July 2007 contained in its condensed consolidated income statements for the 12 month period ended 31 July 2007.

\begin{tabular}{llll}
\hline 20 & Axis & $2007-$ & Director \\
Incorporati & 08 & $\mathrm{~s}$ \\
on Bhd & &
\end{tabular}

Saipuddin Lim and Lee Han Boon were each charged with five counts of furnishing false statements relating to the revenue of Axis Incorporation Berhad ("Axis") to Bursa Malaysia. The charges which were preferred under section $122 \mathrm{~B}(\mathrm{~b})(\mathrm{bb})$ of the Securities Industry Act 1983 (SIA) and section 369(b)(B) of the Capital Markets and Services Act 2007 (CMSA) were in relation to false statements contained in Axis' four quarterly reports for the Financial Year 2007 and the quarter ending 31 March 2008.
RM300,000 for each charge (4 charges).

The director was sentenced to 6 months imprisonment and a fine of RM300,000.

Lee Han Boon was
sentenced to 7
months
imprisonment and
RM200,000 fine.
Saipuddin Lim was
sentenced to 12
months
imprisonment. Koh
Tee Jin was
sentenced to one (1)
day imprisonment
and a fine of
RM200,000.
Lee Han Boon was to 7 months imprisonment and RM200,000 fine. Saipuddin Lim was imprisonment. Koh Tee Jin was sentenced to one (1) day imprisonment and a fine of 


\begin{tabular}{|c|c|c|c|c|c|}
\hline 21 & $\begin{array}{l}\text { Linear } \\
\text { Corporatio } \\
\text { n Bhd }\end{array}$ & 2009 & $\begin{array}{l}\text { Executiv } \\
\mathrm{e} \\
\text { chairma } \\
\mathrm{n} \text { and } \\
\text { Executiv } \\
\mathrm{e} \\
\text { director }\end{array}$ & $\begin{array}{l}\text { Alan Rajendram was charged under } \\
\text { section } 369(\mathrm{~b}) \text { (B) of the Capital } \\
\text { Markets and Services Act } 2007 \\
\text { (CMSA) for furnishing a false } \\
\text { statement to Bursa Malaysia } \\
\text { Securities Bhd in relation to the } \\
\text { affairs of Linear Corporation Berhad } \\
\text { (Linear). The false statement was in } \\
\text { relation to an announcement made } \\
\text { by Linear on } 29 \text { December } 2009 \text { that } \\
\text { its wholly owned subsidiary, LCl } \\
\text { Global Sdn Bhd, had accepted a } \\
\text { RM1.6 billion construction project } \\
\text { awarded by Global Investment } \\
\text { Group, a Seychelles incorporated } \\
\text { company, to design and construct a } \\
\text { district cooling plant of 350,000 RT } \\
\text { (refrigeration tonnes) in Manjung, } \\
\text { Perak, for what was termed as the } \\
\text { 'King Dome Project'. }\end{array}$ & $\begin{array}{l}\text { The director was } \\
\text { sentenced to } 7 \\
\text { months } \\
\text { imprisonment and a } \\
\text { fine of RM100,000 } \\
\text { (in default, } 6 \\
\text { months jail). }\end{array}$ \\
\hline 22 & $\begin{array}{l}\text { Silverbird } \\
\text { Bhd }\end{array}$ & $\begin{array}{l}2010- \\
11\end{array}$ & $\begin{array}{l}\text { Managin } \\
\text { g } \\
\text { director } \\
\text { Chief } \\
\text { Executiv } \\
\text { e Officer }\end{array}$ & $\begin{array}{l}\text { Tan Han Kook and Ching Siew } \\
\text { Cheong were each charged with } \\
\text { seven and eight counts respectively } \\
\text { of furnishing false statements } \\
\text { relating to the revenue of Silver Bird } \\
\text { Group Berhad to Bursa Malaysia. } \\
\text { The charges which were preferred } \\
\text { under section } 369(\mathrm{~b})(\mathrm{B}) \text { of the } \\
\text { Capital Markets and Services Act } \\
2007 \text { (CMSA) were in relation to } \\
\text { false statements contained in Silver } \\
\text { Bird Group Berhad's quarterly } \\
\text { reports for financial years } 2010 \text { and } \\
2011 \text {. }\end{array}$ & $\begin{array}{l}\text { Tan Han Kook and } \\
\text { Ching Siew Cheong } \\
\text { were charged on } 11 \\
\text { September } 2013 \text {. } \\
\text { On } 10 \text { June, they } \\
\text { were acquitted from } \\
\text { all charges. }\end{array}$ \\
\hline
\end{tabular}

Sources: Securities Commission of Malaysia

Table 1.4 above shows that the financial reports were manipulated in three aspects namely audited accounts (11 companies), quarterly reports ( 7 companies) and corporate proposals (4 companies). Next, most of the fraudulent financial reporting cases have been caused by top management consisting of directors, chairman, chief executive officer and financial controller. Brennan \& McGrath (2007) claimed that it is the ability of the top management to override controls and direct others to commit and conceal the fraud that gives rise to fraud. 
INTERNATIONAL JOURNAL OF ACADEMIC RESEARCH IN ACCOUNTING, FINANCE AND MANAGEMENT SCIENCES

Vol. 11, No. 1, 2021, E-ISSN: 2225-8329 @ 2021 HRMARS

Nevertheless, as a consequence of their actions, the law in Malaysia has sentenced them with a rather severe punishment. The highest amount of fine being imposed so far was $R M 2,500,000$. It was imposed on former Chief Executive Officer and Executive Director of Transmile Group Berhad. The lowest amount of fine was RM100,000 which was imposed on the director of Linear Corporation Bhd. With regards to imprisonment, the longest period so far is 2 years. The sentence was imposed on two directors of Kosmo Technology Industrial Bhd. Apart from imprisonment, the two directors were also liable to a total fine of RM1.45 million each.

\section{Conclusion}

The objective of this study is to explore the background of the companies involved in fraudulent financial reporting and the impacts to the offenders as well as the companies after the fraud was revealed by the regulator. This study reveals that most fraudulent financial reporting cases occurred a few years before the introduction MCCG2000 and a few years before the MCCG was revised in 2007. Industrial product sector was the sector most frequently involved in fraudulent financial reporting. The study further discloses that annual report of four fraudulent companies were no longer available in Bursa Malaysia website after the companies were involved in fraud. Thirteen fraudulent companies were delisted after the offence was revealed. Six fraudulent companies were audited by the Big 5 then later the Big 4. The financial reports were manipulated in three aspects namely audited accounts, quarterly reports and corporate proposals. The study also found out that five companies changed name a few years after they were involved in fraud. In most cases, the offenders involved in such fraud scheme were the top management mostly directors. Next, the penalties and sentences imposed on offenders were considered fair in relation to offences committed. The highest amount being fined was $\mathrm{RM} 2,500,000$ and the longest period of imprisonment was 2 years. The limitation of this study is that it only identifies fraudulent companies from the criminal prosecution list of Securities Commission's website. Future research should extend to identify cases under case compounded and media releases of Securities Commission as well as media releases of Bursa Malaysia.

This study makes theoretical and contextual contributes to the existing knowledge in the following ways. Firstly, it highlights a few characteristics of fraudulent companies in Malaysia such as the business sector of the companies, the period fraud frequently occurred and the documents that were manipulated by the offenders. Secondly, it reveals the consequences to the offenders and the companies after the offenders were found guilty by the court. Thirdly, this study can be a source of reference for future research. Finally, it is expected that this study will provide useful information to the business players and regulators in relation to impacts of fraudulent financial reporting on the employment and economic growth of the nation.

\section{References}

Abbott, L., Parker, S., \& Peters, G. (2004). Audit Committee Characteristics and Restatements. Auditing: A Journal of Practice \& Theory, 23(1), 69-87.

ACFE (Association of Certified Fraud Examiners). (2020). Report to the nations on occupational fraud and abuse: 2020 global fraud study. https://www.acfe.com/report-to-the-nations/2020

Al-Rassas, A. H., \& Kamardin, H. (2015). Internal and External Audit Attributes, Audit Committee Characteristics, Ownership Concentration and Earnings Quality: Evidence from Malaysia. 
INTERNATIONAL JOURNAL OF ACADEMIC RESEARCH IN ACCOUNTING, FINANCE AND

MANAGEMENT SCIENCES

Vol. 11, No. 1, 2021, E-ISSN: 2225-8329 @ 2021 HRMARS

Mediterranean Journal of Social Sciences, 6(3), 458-470. https://doi.org/10.5901/mjss.2015.v6n3p458

Azis, N. K., Marzuki, M. M., \& Majid, W. Z. N. A. (2020). Fraud Prevention in Malaysia : Maqasid alShariah Perspective. Global Business and Management Research: An International Journal, 12(2), 104-117.

Badolato, P. G., Donelson, D. C., \& Ege, M. (2013). Audit committee financial expertise and earnings management: The role of status. Journal of Accounting and Economics, 58(2-3), 208-230.

Baek, H. Y., Johnson, D. R., \& Kim, J. W. (2009). Managerial ownership, corporate governance, and voluntary disclosure. The Journal of Business and Economic Studies, 15(2), 44.

Barsky, N. P., Catanach, A. H., \& Rhoades-Catanach, S. C. (2003). Analyst tools for detecting financial reporting fraud. Commercial Lending Review, 18(5), 31-36.

Beasley, M. S. (1996). An emperical analysis of relation between the board of director composition and financial statement fraud. The Accounting Review, 71(4), 443-465.

Bonner, S. E., Palmrose, Z., \& Young, S. M. (1998). Fraud Type and Auditor Litigation: An Analysis of SEC Accounting and Auditing Enforcement Releases. The Accounting Review, 73(4), 503-532.

Brennan, N. M., \& McGrath, M. (2007). Financial Statement Fraud: Some Lessons from US and European Case Studies. Australian Accounting Review, 17(42), 49-61.

Carcello, J. V. J., \& Nagy, A. L. (2004). Audit Firm Tenure and Fraudulent Financial Reporting. Auditing: A Journal of Practice \& Theory, 23(2), 55-69.

Carcello, J. V., \& Palmrose, Z. V. (1994). Auditor litigation and modified reporting on bankrupt clients. Journal of Accounting Research, 32, 1-30.

Carpenter, T. D., \& Reimers, J. L. (2005). Unethical and fraudulent financial reporting: Applying the theory of planned behavior. Journal of Business Ethics, 60(2), 115-129.

Chen, C. R., Guo, W., \& Mande, V. (2006). Corporate value, managerial stockholdings and investments of Japanese firms. Journal of International Financial Management and Accounting, 17(1), 29-51.

Dalnial, H., Kamaluddin, A., Sanusi, Z. M., \& Khairuddin, K. S. (2014). Detecting Fraudulent Financial Reporting through Financial Statement Analysis. Journal of Advanced Management Science, 2(1),

17-22. http://www.joams.com/index.php?m=content\&c=index\&a=show\&catid=36\&id=108

Dechow, P. M., Hutton, A. P., \& Sloan, R. G. (1996). Economic Consequences of Accounting for StockBased Compensation. Journal of Accounting Research, 34(3), 1-20.

Ghafran, C. M. (2013). Audit Committees and Fraudulent Reporting Quality [Doctoral dissertation, The University of Sheffield].

Holtfreter, K. (2005). Is occupational fraud "typical" white-collar crime? A comparison of individual and organizational characteristics. Journal of Criminal Justice, 33(4), 353-365.

Huang, H.-W., \& Thiruvadi, S. (2010). Audit Committee Characteristics And Corporate Fraud. International Journal of Public Information Systems, 6(1), 71-82.

Kaminski, K. A., Wetzel, T. S., \& Guan, L. (2004). Can financial ratios detect fraudulent financial reporting? Managerial Auditing Journal, 19(1), 15-28.

Kanjanapathy, M., \& Hashim, M. M. (2019). Corporate frauds in emerging markets: Cases involving Malaysia companies. International Journal of Recent Technology and Engineering, 7(6), 865-867.

Kinney, W. R., Palmrose, Z. V., \& Scholz, S. (2004). Auditor independence, non-audit services, and restatements: Was the U.S. government right? Journal of Accounting Research, 42(3), 561-588.

Knapp, C. A., \& Knapp, M. C. (2001). The effects of experience and explicit fraud risk assessment in 
INTERNATIONAL JOURNAL OF ACADEMIC RESEARCH IN ACCOUNTING, FINANCE AND

MANAGEMENT SCIENCES

Vol. 11, No. 1, 2021, E-ISSN: 2225-8329 @ 2021 HRMARS

detecting fraud with analytical procedures. Accounting, Organizations and Society, 26(1), 25-37. https://doi.org/10.1016/S0361-3682(00)00005-2

Lau, C. K., \& Ooi, K. W. (2016). A case study on fraudulent financial reporting: evidence from Malaysia. Accounting Research Journal, 29(1), 4-19. https://doi.org/10.1108/ARJ-11-2013-0084

Lavery, C. A., Lindberg, D. L., \& Razaki, K. A. (2000). Fraud awareness in a small business. National Public Accountant, 45(6), 40-42.

Lindsey, C., Leavell, H., \& Tucker, S. H. (2002). Factors That Lead To Audit Failure When Fraudulent Financial Reporting By The Client Is Present. In Allied Academies International Conference. Academy of Legal, Ethical and Regulatory Issues, 6(2).

Lys, T., \& Watts, R. L. (1994). Lawsuits against auditors. Journal of Accounting Research, 32, 65-93.

Zin, M. S. F., Marzuki, M. M., \& Abdulatiff, N. K. (2020). The likelihood of fraudulent financial reporting: The new implementation of Malaysian code of corporate governance (MCCG) 2017. International Journal of Financial Research, 11(3), 84-91.

Nasir, M. N. A., \& Hashim, H. A. (2020). Corporate governance performance and financial statement fraud: evidence from Malaysia. Journal of Financial Crime. https://doi.org/10.1108/JFC-09-20200182

Yusoff, M. N., Ismail, F., Ab Samad, N. H., \& Abd Rahman, N. (2020). Financial Statement Fraud: Evidence from Prospective Accounting Practitioners. International Journal of Innovation, Creativity and Change, 13(3), 1281-1297.

Mitra, S., Hossain, M., \& Deis, D. R. (2007). The empirical relationship between ownership characteristics and audit fees. Review of Quantitative Finance and Accounting, 28(3), 257-285.

Nelson, S. P. (2011). Fraudulent Financial Reporting: A Basic Analysis. IIUM Press, 1-12.

O'Connor, J. P., Priem, R. L., Coombs, J. E., \& Gilley, K. M. (2006). Do CEO stock options prevent or promote fraudulent financial reporting? Academy of Management Journal, 49(3), 483-500.

Owusu-Ansah, S., Moyes, G. D., Oyelere, P. B., \& Hay, D. (2002). An empirical analysis of the likelihood of detecting fraud in New Zealand. Managerial Auditing Journal, 17(4), 192-204. https://doi.org/10.1108/02686900210424358

Park, S. (2017). Audit Quality And Accrual Quality: Do Big 4 Auditors Indeed Enhance. The Journal of Applied Business Research, 33(2), 343-350.

Persons, O. S. O. (1995). Using financial statement data to identify factors associated with Fraudulent Financial Reporting. Journal of Applied Business Research, 11(3), 38-46.

Reinstein, A., Moehrle, S. R., \& Reynolds-Moehrle, J. (2006). Crime and punishment in the marketplace: Accountants and business executives repeating history. Managerial Auditing Journal, 21(4), 420-435.

Saksena, P. (2001). The Relationship Between Environmental Factors and Management Fraud: an Empirical Analysis. International Journal of Commerce and Management, 11(1), 120-139.

Spathis, C. T. (2002). Detecting false financial statements using published data: some evidence from Greece. Managerial Auditing Journal, 17(4), 179-191.

Sulaiman, A. N. M. (2008). Financial misreporting and securities fraud -- public and private enforcement. Australian Journal of Corporate Law, 22(April), 1-20.

Summers, S. L., \& Sweeney, J. T. (1998). Fraudulently misstated financial statements and insider trading : An empirica analysis. The Accounting Review, 73(1), 131-146.

Turpen, R. A., \& Messina, F. M. (1997). Fraud prevention and the management accountant. Management Accounting, 78(8), 34-37. 
INTERNATIONAL JOURNAL OF ACADEMIC RESEARCH IN ACCOUNTING, FINANCE AND

MANAGEMENT SCIENCES

Vol. 11, No. 1, 2021, E-ISSN: 2225-8329 @ 2021 HRMARS

Weidman, S. M., Curatola, A. P., \& Linnehan, F. (2004). A behavioral model of decisions to accrue and disclose environmental liabilities. In American Accounting Association 2004 Mid-Atlantic Region Meeting Paper (Issue January).

Yang, D., Jiao, H., \& Buckland, R. (2017). The determinants of financial fraud in Chinese firms: Does corporate governance as an institutional innovation matter? Technological Forecasting and Social Change, 125, 309-320. 